\title{
Falha na sexagem por inibição do desenvolvimento de embriões bovinos produzidos in vitro com anticorpos anti $\mathrm{H}-\mathrm{Y}$
}

[Failure of sexing by developmental arrest of bovine embryos in vitro produced with $H$-Y antisera]

\author{
M.V.Resende ${ }^{1}$, C.A. Moreira-Filho ${ }^{2}$, C.L.V. Leal ${ }^{3}$, M.F.P.D. Ramalho ${ }^{4}$, A.O. Almeida ${ }^{1}$, \\ R. Vantini ${ }^{1}$, V.F.M. Hossepian de Lima ${ }^{1}$ \\ ${ }^{1}$ Faculdade de Ciências Agrárias e Veterinárias - UNESP \\ Via de Acesso Prof. Paulo Donato Castellane km5 \\ 14884-900 - Jaboticabal, SP \\ ${ }^{2}$ Instituto de Ciências Biomédicas - USP - São Paulo, SP \\ ${ }^{3}$ Faculdade de Zootecnia e Engenharia de Alimentos - USP - Pirassununga, SP \\ ${ }^{4}$ Centro Universitário Anhanguera - UNIFIAN - Leme, SP
}

\begin{abstract}
RESUMO
Embriões bovinos produzidos in vitro, em estádio de mórula, foram cultivados em meio contendo anticorpos anti H-Y de alto título proveniente de ratos por $24 \mathrm{~h}$ e, após este tempo, classificados em dois grupos: 1) embriões inibidos em estádio de mórula (classificados como machos) e 2) embriões que se desenvolveram e formaram a blastocele (classificados como fêmeas). $\mathrm{O}$ sexo de 311 embriões, distribuídos em três grupos de concentração dos anticorpos, $3 \%, 5 \%$ ou $7 \%$, foi identificado pela reação em cadeia da polimerase. Não houve desvio da proporção entre machos e fêmeas $(\mathrm{P}>0,05)$ nos grupos em que se utilizaram os anticorpos anti $\mathrm{H}-\mathrm{Y}$, quando comparadas ao grupo-controle, sem adição de anticorpos anti H-Y. Diferentemente dos resultados obtidos utilizando-se embriões bovinos produzidos in vivo, a sexagem com anticorpos anti $\mathrm{H}-\mathrm{Y}$ de alto título em embriões produzidos in vitro não propiciou sucesso.
\end{abstract}

Palavras-chave: bovino, sexagem de embriões, inibição do desenvolvimento, anticorpos anti H-Y, fecundação in vitro

\begin{abstract}
In vitro produced bovine embryos at morula stage were cultured in medium containing high titer of rat $H$ $Y$ antisera for 24h. The embryos were classified in two groups: 1) embryos arrested at morula stage (classified as males); and 2) embryos that developed and formed a blastocoele (classified as female). The sex of 311 embryos, divided in three groups of concentration of $\mathrm{H}-\mathrm{Y}$ antisera, 3\%, 5\% or 7\%, was identified by polimerase chain reaction. The results showed no difference $(P>0.05)$ on sexual deviation in groups in which the $H-Y$ antisera was added, in relation to control group, in which no $H-Y$ antisera was added. In contrast with results obtained with in vivo produced bovine embryos, the sexing of in vitro produced bovine embryos with high $\mathrm{H}-\mathrm{Y}$ antisera titer did not succed.
\end{abstract}

Keywords: bovine, embryo sexing, developmental arrest, $H-Y$ antisera, in vitro fertilization

\section{INTRODUÇÃO}

A seleção do sexo de embriões bovinos préimplantados produzidos in vitro pode aumentar o ganho genético em programas de acasalamento
(Faber et al., 2003) e diminuir o custo do teste de progênie (Nicholas e Smith, 1983) em bovinos destinados à produção de leite ou carne (Van Vleck et al., 1987). Além disso, a sexagem de embriões pode desviar a proporção entre machos e fêmeas em favor das fêmeas, solucionando a

Recebido em 14 de maio de 2007

Aceito em 6 de março de 2008

E-mail: mvresende@yahoo.com.br 
principal desvantagem do cultivo in vitro de embriões que é o desenvolvimento mais rápido de machos (Avery e Schmidt, 1989).

A sexagem de embriões pode ser feita de duas formas: a) métodos invasivos, que incluem análise citogenética, análise de DNA de seqüências específicas do cromossomo $\mathrm{Y}$ utilizando hibridização in situ com fluorescência (FISH) e PCR; b) métodos não-invasivos, como a quantificação de enzimas ligadas ao cromossomo $\mathrm{X}$ e a detecção por ensaios imunológicos do antígeno $\mathrm{H}-\mathrm{Y}$ masculino. A aplicação de métodos invasivos para a sexagem de embriões é limitada devido a regras sanitárias específicas, pois a zona pelúcida é rompida após a biópsia, impedindo sua comercialização internacional (Ramalho et al., 2004).

Entretanto, embriões masculinos e femininos produzidos in vitro apresentam taxas de desenvolvimento e expressão de genes diferentes se comparados com embriões produzidos in vivo. Essas diferenças incluem modificações morfológicas e atividade genômica (GutierrezAdan et al., 2000).

Considerando-se as leis de controle de doenças e a dificuldade de se conduzir a sexagem de embriões em condições de campo (Ramalho et al., 2004), o objetivo do presente estudo foi testar a eficiência de anticorpos anti $\mathrm{H}-\mathrm{Y}$ de alto título produzidos em ratos em induzir a inibição do desenvolvimento de embriões bovinos, na tentativa de selecionar o sexo durante a produção in vitro.

\section{MATERIAL E MÉTODOS}

Para a produção de anticorpos anti H-Y, oito ratas da linhagem isogênica Wistar Furth, com 45 a 55 dias de idade, foram imunizadas com leucócitos do baço de machos de mesma linhagem. Cada animal recebeu uma injeção intraesplênica $(0,08 \mathrm{ml})$ de $4 \times 10^{7}$ células diluídas em PBS suplementado com $5 \%$ de soro fetal bovino (SFB). Essas fêmeas receberam uma injeção intraperitoneal de reforço $\left(0,1 \mathrm{ml}, 4 \times 10^{7}\right.$ células) 18 dias após a primeira injeção intraesplênica. Após 10 dias, as ratas imunizadas foram sangradas para obtenção e titulação do soro por ELISA (Moreira-Filho e Wachtel, 1985).
Iniciou-se o ELISA pela adição de $100 \mu$ de antígeno H-Y solúvel (sobrenadantes de células de TM-4; Brunner et al., 1984) em cada poço de uma placa de poliestireno para microtitulação ${ }^{1}$, permanecendo a $4^{\circ} \mathrm{C}$ por $12 \mathrm{~h}$. A placa foi lavada por três vezes com PBS $+0,05 \%$ de albumina sérica bovina $\left(\mathrm{BSA}^{2}\right)$, pH 7,2, e uma vez com PBS contendo $3 \%$ de BSA $(\mathrm{pH} 7,2)$ por $3 \mathrm{~h}$ a $37^{\circ} \mathrm{C}$ e lavada novamente por três vezes. Os anticorpos primários (anticorpos anti $\mathrm{H}-\mathrm{Y}$ ) foram adicionados após diluição serial (1:8 a 1:2.048) em PBS $+1 \%$ de BSA. Após a incubação por $60 \mathrm{~min}$ em gelo, a placa foi lavada três vezes com PBS $+0,05 \%$ de BSA, adicionando-se em cada poço anticorpo secundário contra imunoglobulina de rato conjugado com peroxidase $^{3}$, diluído 1:3000 em PBS $+1 \%$ BSA. A placa foi incubada em temperatura ambiente por $60 \mathrm{~min}$ e lavada três vezes com PBS $+0,05 \%$ de BSA. Os poços foram preenchidos com substrato - $1 \mathrm{mg} / \mathrm{ml}$ de ortofenildiamina ${ }^{4}+$ $1 \mu \mathrm{l} / \mathrm{ml}$ de $30 \%$ de peróxido de hidrogênio ${ }^{5}$ diluído em 0,1M, pH 4,5 de tampão citrato - e mantidos sob agitação constante, no escuro, por 15 min. A reação foi interrompida com a adição de $100 \mu 1$ de ácido sulfúrico 4 N. A reação foi lida imediatamente em um leitor de absorbância ${ }^{6}$ com comprimento de onda de $490 \mathrm{~nm}$.

A densidade óptica (DO) dos anticorpos era $\geq 1.1$ na diluição de 1:256, e o ponto de corte dos soros foi um soro negativo de uma rata não submetida à imunização. Os soros com $\mathrm{DO} \geq 1.1$ alcançaram título com diluição de 1:1.024 a 1:2.048. Os soros das ratas, não misturados entre si, não foram adsorvidos com células de fêmeas isogênicas antes da sexagem (Hossepian de Lima et al., 1993).

Os reagentes e meios utilizados para a produção in vitro de embriões foram adquiridos da Sigma ${ }^{2}$, exceto aqueles indicados.

Ovários bovinos foram transportados de abatedouros ao laboratório em solução salina a uma temperatura de 28 a $35^{\circ} \mathrm{C}$. Folículos antrais,

\footnotetext{
${ }^{1}$ Linbro/Titertek. Flow Laboratories Inc. McLean, EUA.

${ }^{2}$ Sigma-Aldrich. Saint Louis, EUA.

${ }^{3}$ Goat Anti-Rat Ig $(\mathrm{H}+\mathrm{L})$ HRP. Southern Biotech

Associates. Alabama, EUA

${ }^{4}$ Streptavidin. Bethesda Research Laboratories. Bethesda,

EUA.

${ }^{5}$ Perdrogen 30. Riedel-de Haën. Seelze, Alemanha.

${ }^{6}$ MRC-TC Plus. Dynex Technologies. Virginia, EUA.
} 
3 a $7 \mathrm{~mm}$, foram aspirados manualmente com uma agulha de 18-gauge acoplada a uma seringa de $20 \mathrm{ml}$. Os oócitos com cumulus compacto e pelo menos com quatro camadas foram selecionados para a maturação in vitro (MIV). Grupos de 20 a 25 oócitos foram colocados em gotas de $100 \mu$ l do meio sob óleo mineral. O meio de MIV foi o TCM-1997, suplementado com $10 \%$ de SFB inativado pelo calor $\left(55^{\circ} \mathrm{C}\right.$ por $30 \mathrm{~min})$, FSH $\left(1,0 \mu \mathrm{g} / \mu \mathrm{l}\right.$, Ovagen $\left.{ }^{8}\right), \mathrm{hCG}(10 \mathrm{U} / \mathrm{ml}$, Profasi $\left.\mathrm{HP}^{9}\right)$, estradiol $(1,0 \mu \mathrm{g} / \mathrm{ml})$, piruvato de sódio $(0,25 \mathrm{mM})$ e $16,67 \mu \mathrm{g} / \mu \mathrm{l}$ de $\operatorname{amicacina}^{10}$ $(75 \mu \mathrm{g} / \mathrm{ml})$. Os oócitos foram cultivados por 24 a $26 \mathrm{~h}$ à temperatura de $38,5^{\circ} \mathrm{C}$, sob atmosfera de $5 \%$ de $\mathrm{CO}_{2}$ em ar.

Para a fecundação in vitro (FIV), o sêmen foi descongelado a $35^{\circ} \mathrm{C}$ por 40 seg. Os espermatozóides móveis foram obtidos por centrifugação em gradiente de densidade descontínuo (45\%:90\%) de Percoll ${ }^{11}$ ) por $30 \mathrm{~min}$ a $900 x g$. Espermatozóides viáveis foram colhidos da parte inferior da fração de $90 \%$ do gradiente, foram contados e diluídos em meio FIV $\left(100 \times 10^{3}\right.$ células para uma gota de FIV de $90 \mu 1$ ), e incubados por 60min para capacitação. Os oócitos foram lavados três vezes em meio TCM- $199^{8}$ suplementado com $25 \mathrm{mM}$ de HEPES, $100 \mathrm{mM}$ de piruvato de sódio, $\mathrm{BSA}^{12}(10 \mathrm{mg} / \mathrm{ml}$; fração $\mathrm{V}$, livre de ácidos graxos) e uma vez em meio FIV. Os oócitos e os espermatozóides foram incubados por $20 \mathrm{~h}$ em $5 \%$ de $\mathrm{CO}_{2}$, em atmosfera úmida à temperatura de $38,5^{\circ} \mathrm{C}$. Os prováveis zigotos foram desnudados por repetidas pipetagens, lavados três vezes no meio modificado "synthetic oviduct fluid" (SOF; Vajta et al., 1999), e transferidos para $500 \mu 1$ de meio SOF em uma placa de quatro poços. O cultivo dos embriões foi realizado sob óleo mineral na atmosfera úmida de $5 \%$ de $\mathrm{CO}_{2}, 5 \%$ de $\mathrm{O}_{2}$ e $90 \%$ de $\mathrm{N}_{2}$ a $38,5^{\circ} \mathrm{C}$ por aproximadamente cinco dias, quando os embriões alcançaram o estádio de mórula. Durante o cultivo in vitro, não foi adicionado SFB, como descrito previamente (Gutierrez-Adan et al., 2001).

Realizaram-se cinco repetições, em diferentes dias, utilizando-se três concentrações do soro contendo anticorpos anti H-Y: 3\% de soro, com 113 embriões, 5\% de soro com 96 embriões e $7 \%$ de

\footnotetext{
${ }^{7}$ Gibco BRL. Grand Island, EUA.

${ }^{8}$ Immuno-Chemical Products Ltd. Auckland, Nova Zelândia.

${ }^{9}$ Laboratoires Serono S.A. Aubonne, Suíça.

${ }^{10}$ Aminocina. Instituto Biochimico Ltda.. São Paulo, Brasil.

${ }^{11}$ Amersham Pharmacia Biotech AB. Uppsala, Suécia.

${ }^{12}$ Inlab. São Paulo, Brasil
}

soro com 102 embriões. Em um primeiro teste foi adicionado $10 \%$ de soro contendo anticorpos anti $\mathrm{H}-\mathrm{Y}$ no meio de cultivo, no entanto, os embriões degeneraram e, desse modo, reduziu-se a concentração máxima do soro. Aproximadamente cinco dias após a FIV, os anticorpos anti $\mathrm{H}-\mathrm{Y}$ foram adicionados no meio de cultivo contendo embriões bovinos. O grupo-controle, com 115 embriões, foi incubado sem anticorpos anti H-Y. Este grupocontrole foi necessário para monitoramento do desvio da proporção entre machos e fêmeas para machos durante o cultivo in vitro e para verificar a partenogênese. Os grupos da sexagem e o controle foram incubados a $38,5^{\circ} \mathrm{C}, 5 \%$ de $\mathrm{CO}_{2}, 5 \%$ de $\mathrm{O}_{2} \mathrm{e}$ $90 \%$ de $\mathrm{N}_{2}$ por $24 \mathrm{~h}$.

Após esse período, os embriões do grupo da sexagem foram separados em dois grupos, de acordo com o estádio de desenvolvimento alcançado após a incubação em meio contendo anticorpos anti H-Y. Embriões inibidos em estádio de mórula, presumidamente $\mathrm{H}-\mathrm{Y}$ positivos e classificados como machos, constituíram o grupo 1; embriões que progrediram para o estádio de blastocisto, presumidamente $\mathrm{H}-\mathrm{Y}$ negativos $\mathrm{e}$ classificados como fêmeas, constituíram o grupo 2 .

Para a determinação do sexo genético dos embriões pela PCR, 311 embriões dos grupos da sexagem e 115 embriões do grupo-controle (sem adição de soro contendo anticorpos anti H-Y) foram colocados em tubos de $0,2 \mathrm{ml}$ para PCR contendo $10 \mu \mathrm{l}$ de água ultra-pura autoclavada. Posteriormente, foi adicionada Proteinase $\mathrm{K}^{13}$ na concentração final de $50 \mu \mathrm{g}$ por embrião. Os tubos foram incubados a $37^{\circ} \mathrm{C}$ por $60 \mathrm{~min}$ (para ação da enzima) e a $98^{\circ} \mathrm{C}$ por $10 \mathrm{~min}$ (para inativação da enzima). Dois pares de "primers" Y-específicos foram adicionados em duas amostras distintas. $\mathrm{O}$ primeiro par foi: 5' - CCT CCC CTT GTT CAA ACG CCC GGA ATC ATT - 3' e 5' - TGC TTG ACT GCA GGG ACC GAG AGG TTT GGG - 3' (Bondioli et al., 1989); e o segundo par foi: 5' ATC AGT GCA GGG ACC GAG ATG - 3' e 5' AAG CAG CCG ATA AAC ACT CCT T - 3' (Schwerin et al., 1991; Luz et al., 2000). O primeiro par detecta uma seqüência de $210 \mathrm{pb}$ do cromossomo $\mathrm{Y}$ bovino e o segundo, uma seqüência de 196pb do cromossomo Y. Um terceiro par detecta uma seqüência autossômica de $280 \mathrm{pb}$, indicando a presença de DNA genômico bovino. O terceiro par foi: $5^{\prime}$ - AGG TCG CGA GAT TGG TCG CTA GGT CAT GCA - 3' e 5' - AAG ACC TCG AGA GAC CCT CTT CAA CAC GT - 3'

${ }^{13}$ Invitrogen. Carlsbad, EUA. 
(Ellis e Harpold, 1986; Ellis et al., 1988). "PCR multiplex" foi realizada em um mesmo tubo com o primeiro (210pb) e o terceiro (280pb) "primers", a PCR com o segundo par de "primers" (196pb) o foi em outro tubo. As amplificações foram feitas em um termociclador ${ }^{14}$, da seguinte forma: a) para o primeiro e terceiro par de "primers": um passo inicial a $94^{\circ} \mathrm{C}$ por $5 \mathrm{~min}, 40$ ciclos a $94^{\circ} \mathrm{C}$ por $1 \mathrm{~min}$ de desnaturação, anelamento a $58^{\circ} \mathrm{C}$ por 30 seg e síntese a $72^{\circ} \mathrm{C}$ por $1 \mathrm{~min}$, e uma extensão final de 7 min a $72^{\circ} \mathrm{C}$, com total de 40 ciclos; b) para o segundo par de "primers", um passo inicial de $94^{\circ} \mathrm{C}$ por $5 \mathrm{~min}, 38$ ciclos a $94^{\circ} \mathrm{C}$ por $1 \mathrm{~min}$ de desnaturação, anelamento a $58^{\circ} \mathrm{C}$ por $1 \mathrm{~min}$ e síntese a $72^{\circ} \mathrm{C}$ por $1 \mathrm{~min}$ e uma extensão final de 7 min a $72^{\circ} \mathrm{C}$, total de 38 ciclos.

Os resultados obtidos a partir da identificação do sexo genético dos embriões foram submetidos à análise estatística pelo teste do qui-quadrado a $5 \%$ de significância. Confrontou-se, separadamente, cada grupo da sexagem - $3 \%, 5 \%$ ou $7 \%$ de soro contendo anticorpos anti H-Y durante a produção in vitro dos embriões - com o grupo-controle - não adicionado soro contendo anticorpos anti H-Y -, verificando-se o desvio da proporção entre machos e fêmeas dos embriões em estádio de mórulas (classificados como machos) e em estádio de blastocistos (classificados como fêmeas).

\section{RESULTADOS}

A identificação de embriões e os resultados da PCR de 311 embriões cultivados em meio contendo anticorpos anti H-Y são apresentados na Fig. 1 e na Tab. 1. Ocorreram falhas em inibir o desenvolvimento de embriões bovinos produzidos in vitro, pois não houve diferença quando se comparou com a proporção entre machos e fêmeas obtida no grupo-controle, que foi de $54 \%$ de machos e de $46 \%$ de fêmeas em 115 embriões. Desse modo, não houve necessidade de comparar os grupos da sexagem entre si.

Tabela 1. Resultados da PCR após a sexagem de embriões bovinos produzidos in vitro por inibição do desenvolvimento por anticorpos anti $\mathrm{H}-\mathrm{Y}$

\begin{tabular}{|c|c|c|c|c|c|c|c|c|c|c|c|c|}
\hline \multirow{3}{*}{$\begin{array}{l}\text { Estádio do } \\
\text { embrião } \\
\text { (sexo } \\
\text { provável) }\end{array}$} & \multicolumn{12}{|c|}{ Embriões sexados pela PCR - n (\%) } \\
\hline & \multicolumn{3}{|c|}{$\begin{array}{c}\text { Grupo de } 3 \% \text { de anticorpos } \\
\text { anti H-Y }\end{array}$} & \multicolumn{3}{|c|}{$\begin{array}{c}\text { Grupo de } 5 \% \text { de anticorpos } \\
\text { anti H-Y }\end{array}$} & \multicolumn{3}{|c|}{$\begin{array}{c}\text { Grupo de } 7 \% \text { de anticorpos } \\
\text { anti H-Y }\end{array}$} & \multicolumn{3}{|c|}{ Grupo-controle } \\
\hline & $\mathrm{n}$ & Macho & Fêmea & $\mathrm{n}$ & Macho & Fêmea & $\mathrm{n}$ & Macho & Fêmea & $\mathrm{n}$ & Macho & Fêmea \\
\hline $\begin{array}{l}\text { Mórula } \\
\text { (macho) }\end{array}$ & 61 & $\begin{array}{c}29 \mathrm{a} \\
(47,5 \%)\end{array}$ & $\begin{array}{c}32 \mathrm{a} \\
(52,5 \%)\end{array}$ & 43 & $\begin{array}{c}22 \mathrm{a} \\
(51,1 \%)\end{array}$ & $\begin{array}{c}21 \mathrm{a} \\
(48,9 \%)\end{array}$ & 50 & $\begin{array}{c}23 \mathrm{a} \\
(46 \%)\end{array}$ & $\begin{array}{c}27 \mathrm{a} \\
(54 \%)\end{array}$ & & & \\
\hline $\begin{array}{l}\text { Blastocistos } \\
\text { (fềmea) }\end{array}$ & 52 & $\begin{array}{c}30 \mathrm{a} \\
(57,7 \%)\end{array}$ & $\begin{array}{c}22 \mathrm{a} \\
(42,3 \%)\end{array}$ & 53 & $\begin{array}{c}28 \mathrm{a} \\
(52,3 \%)\end{array}$ & $\begin{array}{c}25 \mathrm{a} \\
(47,7 \%)\end{array}$ & 52 & $\begin{array}{l}26 \mathrm{a} \\
(50 \%)\end{array}$ & $\begin{array}{c}26 \mathrm{a} \\
(50 \%)\end{array}$ & & & \\
\hline $\begin{array}{l}\text { Total de } \\
\text { embriões }\end{array}$ & 113 & - & - & 96 & - & - & 102 & - & - & 115 & $\begin{array}{c}61 \\
(54 \%)\end{array}$ & $\begin{array}{c}54 \\
(40 \%)\end{array}$ \\
\hline
\end{tabular}

Letras iguais na linha, dentro de cada grupo, indicam que não houve diferença na proporção de sexos $(\mathrm{P}>0,05)$

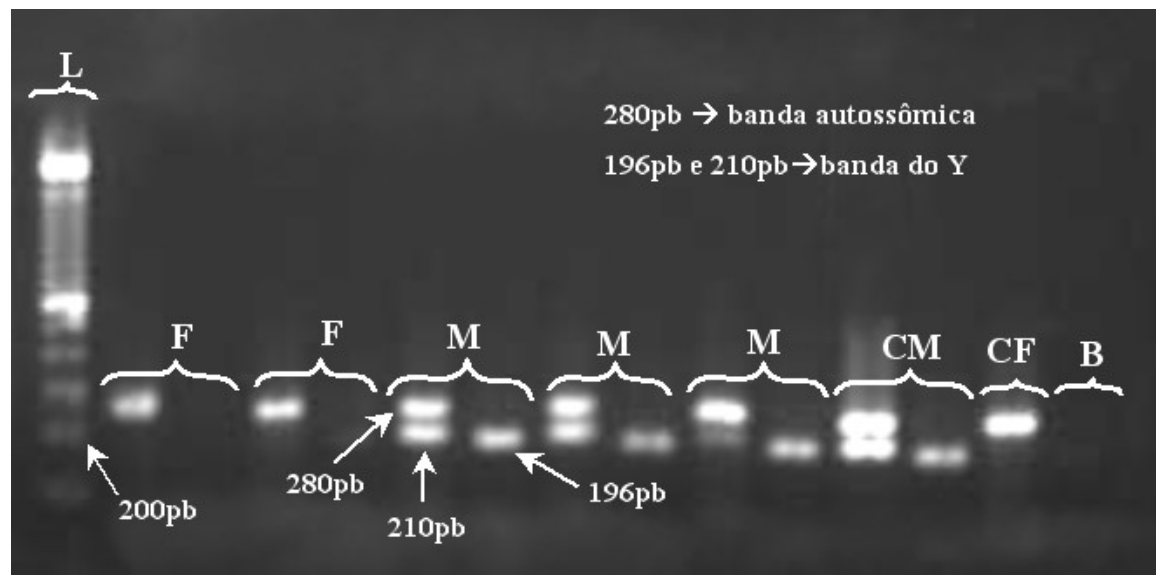

Figura 1. Gel de agarose a 1,5\% com os produtos da PCR de embriões sexados, visualizando-se fragmentos de $280 \mathrm{pb}$ (banda autossômica), 196pb (banda do Y) e 210pb (banda do Y), [L (marcador de peso molecular 100pb), F (embrião fêmea), M (embrião macho), CM (controle macho), CF (controle fêmea) e B (branco - sem amostra de DNA)].

\footnotetext{
${ }^{14}$ MJ Research PTC 100 Thermal Cycler. GMI Inc. Minnesota, EUA.
} 


\section{DISCUSSÃO}

O aperfeiçoamento de técnicas imunológicas para a sexagem de embriões depende da obtenção de soro que contenha altos títulos de anticorpos anti $\mathrm{H}-\mathrm{Y}$ e do desenvolvimento de protocolos simples para minimizar a manipulação dos embriões (Shalev et al., 1978; Bradley e Heslop, 1985; Ramalho et al., 2004). Muitos dos anticorpos policlonais produzidos em camundongos ou ratos apresentam baixo título, limitando a eficiência da sexagem de embriões. Além disso, a produção de anticorpos monoclonais não melhora significativamente a acurácia na determinação do sexo de embriões bovinos (Hossepian de Lima et al., 1993).

No presente estudo, anticorpos anti $\mathrm{H}-\mathrm{Y}$ policlonais de rata com alto título foram produzidos e usados com $\mathrm{DO} \geq 1.1$ na diluição de 1:256 para a sexagem de embriões bovinos produzidos in vitro. Confirma-se, desse modo, que a imunização intraesplênica em ratas isogênicas, com células esplênicas de machos de mesma linhagem, promove uma forte resposta contra o H-Y (Bradley e Heslop, 1985; Ramalho et al., 2004).

No protocolo usado, os anticorpos anti H-Y não foram adsorvidos com células de ratas antes do seu uso no procedimento de sexagem. Vários autores recomendam a adsorção na tentativa de reduzir as reações inespecíficas (Utsumi e Iritani, 1986; Utsumi et al., 1993). No entanto, as observações de Hossepian de Lima et al. (1993), que adsorveram e não adsorveram os anticorpos anti $\mathrm{H}-\mathrm{Y}$, não diferiram significativamente em relação a sua eficiência. De outro modo, está confirmado que a imunização intraesplênica promove forte resposta na produção de anticorpos policlonais anti $\mathrm{H}-\mathrm{Y}$ de alto título como proposto por Bradley e Heslop (1985).

Ao trabalharem com embriões produzidos in vivo de camundongos e bovinos, Ramalho et al. (2004) conseguiram em torno de $80 \%$ de identificação correta entre mórulas e blastocistos. Com mórulas bovinas produzidas in vitro, Gardon et al. (2004) conseguiram $81,7 \%$ de identificação correta na sexagem, utilizando anticorpos anti $\mathrm{H}-\mathrm{Y}$ policlonais adicionados de complemento, que foi produzido em porquinho da Guiné. No entanto, diferentemente do método proposto neste estudo, Gardon et al. (2004) relataram que em torno de $59 \%$ dos embriões degeneraram após o tratamento devido à utilização do complemento. Este fato, que descaracteriza a técnica como sendo somente de inibição do desenvolvimento, impede o uso dos embriões bovinos machos em programas de acasalamento em que este sexo é o desejado.

Os resultados diferem dos citados na literatura e podem ser atribuídos à qualidade morfológica mais baixa dos embriões produzidos in vitro quando comparada com a dos embriões produzidos in vivo. As possíveis explicações para o insucesso dessa técnica podem ser resultado da baixa qualidade das mórulas produzidas in vitro e da clivagem assíncrona, que aumenta a porcentagem de falso-positivos (Wright e Ellington, 1995; Rizos et al., 2001), ou, também, da influência do meio de cultivo usado durante a produção in vitro dos embriões com anticorpos anti H-Y. Uma outra hipótese, para justificar os resultados do presente trabalho, pode ser atribuída às alterações na expressão de genes e moléculas que são responsáveis pela correta ação de antígenos de histocompatibilidade, como o antígeno H-Y. Por exemplo, uma das funções da beta-2-microglobulina é ligar o antígeno $\mathrm{H}-\mathrm{Y}$ na superfície celular (Fellous et al., 1978; Tanaka et al., 2005). Pelo menos em embriões clonados, foi verificada uma expressão anormal nos antígenos de histocompatibilidade classe 1 (Hill et al., 2002).

\section{AGRADECIMENTOS}

Ao CNPq pelo apoio parcial (bolsa de estudo Brasil).

À Dra. Maria Notomi Sato - USP - São Paulo, pela doação dos ratos isogênicos.

\section{REFERÊNCIAS BIBLIOGRÁFICAS}

AVERY, B.; SCHMIDT, M. Sex determination of bovine embryos using H-Y antisera. Acta Vet. Scand., v.30, p.155-164, 1989.

BONDIOLI, K.R.; ELLIS, S.B.; PRYOR, J.H. et al. The use of male-specific chromosomal DNA fragments to determine the sex of bovine preimplantation embryos. Theriogenology, v.31, p.95104, 1989.

BRADLEY, M.P.; HESLOP, B.F. Elicitation of a rapid and transient antibody response to $\mathrm{H}-\mathrm{Y}$ antigens 
by intrasplenic immunization. Transplantation, v.39, p.634-638, 1985.

BRUNNER, M.; MOREIRA-FILHO, C.A.; WACHTEL, G. et al. On the secretion of the H-Y antigen. Cell, v.37, p.615-619, 1984.

ELLIS, S.B.; BONDIOLI, K.R.; WILLIAMS, M.E. et al. Sex determination of bovine embryos using malespecific DNA probes. Theriogenology, v.29, p.242, 1988.

ELLIS, S.B.; HARPOLD, M.M. Nucleic acid probes for prenatal sexing. Genebra: International application published under the Patent Cooperative Treaty (PCT) World Intellectual Property Organization, 1986. (Publication no. WO 86/07095).

FABER, D.C.; MOLINA, J.A.; OHLRICHS, C.L. et al. Commercialization of animal biotechnology. Theriogenology, v.59, p.125-138, 2003.

FELLOUS, M.; GUNHER, E.; KEMLER, R. et al. Association of the H-Y male antigen with $\beta 2$ microbulin on human lymphoid and differentiated mouse tetarocarcinoma cell lines. J. Exp. Med., v.147, p.58-70, 1978 .

GARDON, J.C.; AGUERA, A.; CASTEJON, F. Sexing in vitro produced bovine embryos, at different stages of development, using rat $\mathrm{H}-\mathrm{Y}$ antiserum. Theriogenology, v.62, p.35-43, 2004.

GUTIERREZ-ADAN A.; LONERGAN, P.R.; RIZOS, $D$. et al. Effect of the in vitro culture system on the kinetics of blastocyst development and sex ratio of bovine embryos. Theriogenology, v.55, p.1117-1126, 2001.

GUTIERREZ-ADAN, A.; OTER, M.; MARTINEZMADRID, B. et al. Differential expression of two genes located on the $\mathrm{X}$ chromosome between male and female in vitro-produced bovine embryos at the blastocyst stage. Mol. Reprod. Dev., v.55, p.146-151, 2000.

HILL, J.R.; SCHLAFER, D.H.; FISHER, P.J. et al. Abnormal expression of trophoblast Major Histocompatibility Complex Class I Antigen in cloned bovine pregnancies is associated with a pronounced endometrial lymphocytic response. Biol. Reprod., v.67, p.55-63, 2002.

HOSSEPIAN DE LIMA, V.F.M.; MOREIRA-FILHO, C.A.; DE BEM, A.R. et al. Sex determination of murine and bovine embryos using cytoxicity and immunofluorescence assays. Theriogenology, v.39, p.1343-1352, 1993.

LUZ, M.R.; WATANABE, Y.F.; FERRO, J.A. et al. Sexing in vitro fertilized bovine embryos by multiplex
PCR. Braz. J. Vet. Res. Anim. Sci., v.37, p.453-456, 2000.

MOREIRA-FILHO, C.A.; WACHTEL, S.S. Study of $\mathrm{H}-\mathrm{Y}$ antigen in abnormal sex determination with monoclonal antibody and an ELISA. Am. J. Med. Genet., v.20, p.525-534, 1985.

NICHOLAS, F.W.; SMITH, C. Increased rates of genetic change in dairy cattle by embryo transfer and splitting. Anim. Prod., v.36, p.341-353, 1983.

RAMALHO, M.F.P.D.-T.; GARCIA, J.M.; ESPER, C.R. et al. Sexing of murine and bovine embryos by developmental arrest induced by high-titer H-Y antisera. Theriogenology, v.62, p.1569-1576, 2004.

RIZOS, D.; WARD, F.; BOLAND, M.P. et al. Effect culture system on the yield and quality of bovine blastocysts as assessed by survival after vitrification. Theriogenology, v.56, p.1-16, 2001.

SHALEV, A.; BERCZI, I.; HAMERTON, J.L The H$\mathrm{Y}$ antigen production of antibodies, detection and cross-reaction between mouse, rat and human. Cytogenet. Cell. Genet., v.22, p.672-675, 1978.

SCHWERIN, M.; BLOTTNER. S.; THOMSEN, D. et al. Quantification of $\mathrm{Y}$ chromosome bearing spermatozoa of cattle using in situ hybridization. Mol. Reprod. Dev., v.30, p.39-43, 1991.

TANAKA, T.; EBATA, T.; TAJIMA, A. et al. Beta2Microbulin required for cell surface expression of blastocyst MHC. Biochem. Biophys. Res. Commun., v.332, p.311-317, 2005.

UTSUMI, K.; HAYASHI, M.; TAKAKURA, R. et al. Embryo Sex selection by a rat male-specific antibody and cytogenetic and developmental confirmation in cattle embryos. Mol. Reprod. Dev., v.34, p.25-32, 1993.

UTSUMI K.; IRITANI A. Characteristics of an antitestis antibody effective in sexing rat embryos. Theriogenology, v.26, p.206, 1986.

VAJTA, G.; RINDOM, N.; PEURA, T.T. et al. The effect of media, serum and temperature on in vitro survival of bovine blastocysts after open pulled straw (OPS) vitrification. Theriogenology, v.52, p.939-948, 1999.

VAN VLECK, L.D.; POLLAK, E.J., BRANDFORD OLTENACU, E.A. Genetics for the animal science. Stoneham: W.H. Freeman, 1987. cap. 13, p.287-313.

WRIGHT, R.; ELLINGTON, J. Morphological and physiological differences between in vivo and in vitroproduction preimplantation embryos. Theriogenology, v.44, p.1167-1189, 1995. 